\title{
Perancangan Personal Branding Michael Aldi untuk Berkontribusi dalam Menghadapi College Depression pada Mahasiswa
}

\author{
Yesica Suyanti ${ }^{1 *}$, Maria Nala Damajanti ${ }^{2}$, Cindy Muljosumarto ${ }^{3}$ \\ 1,2,3 Program Studi Desain Komunikasi Visual, Fakultas Seni dan Desain \\ Universitas Kristen Petra, Jl. Siwalankerto No.121-131, Surabaya \\ *Penulis korespondensi; E-mail: yesicasuyanti@gmail.com
}

\begin{abstract}
Abstrak
College depression merupakan depresi yang dialami oleh banyak mahasiswa dikarenakan perasaan tertekan dari bertambahnya tanggung jawab serta gaya hidup yang tidak sehat. Maka dari itu mahasiswa membutuhkan sebuah sosok atau media yang dekat dan dapat menghibur mereka, yaitu musik. Musik menjadi media yang praktis dan dapat dilakukan bersamaan disaat mereka menyelesaikan tanggung jawab mereka. Michael Aldi merupakan musisi baru dan dekat dengan mahasiswa. Michael Aldi menginginkan musiknya dapat memberikan dampak positif dan membantu pendengarnya, namun musik Michael Aldi belum tersampaikan kepada target dengan tepat karena belum memiliki Brand Identity yang jelas. Lewat perancangan dengan menggunakan metode analisis SWOT dan Product Life Cycle dapat menghasilkan personal brand serta konten media yang dapat meningkatkan awareness dan mengurangi tekanan college depression pada mahasiswa. Hasil dari perancangan menunjukan bahwa perasaan sendiri dapat menimbulkan banyak dampak buruk bagi mahasiswa yang sedang mengalami tekanan sehingga besar peran sosok teman dalam kehidupan mahasiswa, seseorang teman yang dapat mengerti memahami yang mereka rasakan sehingga mereka merasa tidak sendiri serta dapat menghibur untuk mengurangi tekanan mereka.
\end{abstract}

Kata kunci: College Depression, Personal Brand, Michael Aldi, Musisi Independent.

\begin{abstract}
College depression is a form of depression that many college students are going through induced by the pressure of increasing responsibilities and unhealthy lifestyle. Therefore, college students need a figure or media that is familiar and consoling, which is music. Music becomes an accessible media that they can listen to as they progress through completing their responsibilities. Michael Aldi is a new musician that is closely acquainted with college students. Through his music, Michael Aldi desires to be able to bring a positive impact and to be a support for listeners. However, Michael Aldi's music has not been effectively communicated to the target as a result of not having a distinct Brand Identity. By creating a design strategy that utilizes SWOT Analysis and Product Life Cycle methodology will result in a personal brand and media content that will raise awareness and help reduce pressure caused by college depression. Results show that loneliness can inflict adverse effects to college students that is going through stress. Thus, a figure of friend plays a big role in their lives; a friend that understands what they are going through so as to make them feel not alone and be consoled, which eventually lessen the stress that they are experiencing.
\end{abstract}

Keywords: College Depression, Personal Brand, Michael Aldi, Independent Musician.

\section{Pendahuluan}

Setiap orang pasti akan mengalami transisi hidup, salah satunya dari remaja ke dewasa. Masa transisi ini terjadi saat seseorang melanjutkan studinya ke perguruan tinggi, walaupun terlihat sebagai masa transisi yang wajar, tidak semua orang dapat melewatimasa transisi dengan baik. Bahkan, cukup banyak ditemukan mahasiswa depresi pada masa transisi ini. Dalam dunia medis Mayo Clinic, depresi ini disebut dengan istilah 'College Depression'.

Berdasarkan laporan Student Minds: Grand Challenges in Student Mental Health (2014), stres termasuk dalam sepuluh kesulitan besar bagi mahasiswa terkait kesehatan mental. Dilansir 
oleh Tirto.id, Indonesia sejak Mei 2016 sampai Desember 2018, dari beragam pemberitaan online mencatat ada 20 kasus bunuh diri mahasiswa.

College depression dapat ditangani dengan banyak cara. Cara paling dekat dan sederhana adalah bercerita dengan teman serta meredakan tekanan yang ada dalam diri mereka lewat media bantu salah satunya musik.

Menurut Kemper \& Danhauer (2005), musik dapat meringankan rasa sakit, perasaan serta pikiran negatif atau tidak menyenangkan dan dapat membantu mengurangi rasa cemas yang ada didalam diri seseorang tersebut. Dalam kesimpulan studidiskusi Medical Daily (2014) musik adalah cara efisien dan efektif biaya dalam pengobatan depresi pada anak dan remaja. Musik menjadi teman bagi pendengar dalam melakukan aktivitas sehari hari termasuk dikalangan mahasiswa. Hal ini menjadikan musik sebagai salah satu media paling dekat dengan mahasiswa. Dengan menggabungkan fungsi musik dapat menghasilkan media yang dapat berkontribusi membantu permasalahan College Depression.

Seorang musisi dari Surabaya, Michael Aldi dapat menjadi media bantu dari permasalahan college depression. Michael Aldi telah terjun ke dunia entertainment musik sejak 2014. Setelah memutuskan untuk membuat musiknya sendiri, hasil karya musik Michael Aldi ternyata cenderung membahas tentang permasalahan college depression, karena Michael Aldi menciptakan lagu sesuai dengan pengalaman pribadinya yang juga merupakan seorang mahasiswa. Michael Aldi menginginkan musiknya dapat memberikan dampak positif dan membantu pendengarnya, namun musik Michael Aldi belum tersampaikan kepada target dengan tepat karena belum memiliki Brand Identity yang jelas.

Dengan perancangan ini dapat memberikan brand identity Michael Aldi sebagai musisi sehingga semakin terarah dan hasil musik yang Michael Aldi ciptakan dapat bermanfaat lebih tepat, dekat dengan sasaran sehingga mengembangkan karirnya lebih profesional lagi di dunia musik Indonesia serta dapat menjawab permasalahan perancangan ini yaitu membantu mahasiswa dalam menurunkan tekanan college depression.

\section{Metode Analisis}

Metode penelitian deskriptif kualitatif menurut Jenn dan Ken Visocky O'Grady (2006: 18) adalah metode riset yang berhubungan dengan subjek material seperti teks dan gambar. Metode ini dapat memahami dan menemukan ciri khusus dari prosesnya. Perancangan ini menggunakan pendekatan etnografi yaitu menguraikan dan menafsirkan pola bersama dari nilai-nilai, perilaku, keyakinan, dan bahasa dari berbagai kelompok sosial atau untuk mempelajari budaya sosial.

Perancang memilih metode ini karena dengan deskriptif kualitatif dapat membuat data gambaran secara sistematis, faktual, dan akurat yang dapat disusun menjadi rumusan untuk menjawab permasalahan dalam perancangan ini.

Perancangan ini juga menggunakan analisis SWOT, yaitu melakukan evaluasi kekuatan (strengths), kelemahan (weaknesses), peluang (opportunities), dan ancaman (threats) dari kompetitor Michael Aldi dan kondisi untuk mencari potensi Michael Aldi sekarang. Metode ini digunakan saat proses pembuatan personal branding Michael Aldi.

Metode Product Life Cycle dapat digunakan untukmenganalisis produk agar dapat menentukan strategi tahapan apa yang cocok untuk objek perancangan. Metode ini menyangkut proses produk dari proses pengembangan (development), pengenalan, (introduction), pertumbuhan (growth), kejenuhan (maturity), dan penurunan (decline) (Wiryawan, 2008).

Product Life Cycle terdiri dari analisis $4 \mathrm{P}$ yaitu product, price, promotion, place serta kompetitor. Dalam perancangan ini akan menganalisis dari karya, dan promosi yang telah dilakukan Michael Aldi selama ini. Lewat metode ini akan menemukan posisi produk Michael Aldi berada di tahapan apa agar strategi yang dihasilkan dapat menjawab permasalahan perancangan ini.

\section{Personal Branding}

Menurut Dewi Haroen (2014) personal brand merupakan sebuah bentuk persepsi yang dimiliki masyarakat terhadap aspek seorang persona, yaitu kepribadian, kemampuan, atau nilai-nilai, dan mampu menimbulkan persepsi positif yang dapat digunakan sebagai alat pemasaran serta media untuk memecahkan masalah. Pada era digital seperti sekarang keadaan persaingan antar personal brand sudah semakin luas dan terbuka, maka dari itu sangat penting dibutuhkan arahan personal 
branding yang tepat. Selain setiap orang pasti memiliki personal brand, namun kebanyakan orang tidak menyadari ini dan tidak mengembangkannya secara konsisten, efektif serta dengan strategi yang tepat (Rampersad, 2008).

Menurut Kedher (2010) tahapan personal branding dibagi menjadi tiga bagian yaitu yang pertama proses pembentukan identity atau keunikan pada personal brand, setelah itu dilanjutkan dengan proses positioning atau penyampaian komunikasi kepada sasaran, yang terakhir dengan proses pengevaluasian atau disebut djuga dengan assessment. Tiga tahapan tersebut adalah:

\section{a. Personal Branding Identity}

Proses pembuatan identitas yang akan di terapkan pada benak sasaran. Proses ini terdiri dari pengumpulan data sasaran, membaca situasi serta mencari kompotensi yang dimiliki. Setelah itu menentukan objektif dari persona yang dibuat sehingga relevan dengan permintaan sasaran. Terdiri dari dua faktor yaitu:

1. Role Standart adalah nilai atau essence dari sebuah persona yang menjadi inti atau jiwa yang dibentuk dari persona tersebut. Lewat role standart, akan menjadi ide pokok turunan bagi setiap desain atau ide strategi yang dibentuk pada proses positioning.

2. Role Style merupakan sifat subjektif dari role standart, hasil turunan dari essence personal yang sejalan dengan kompetensi dan nilai yang dibentuk. Dalam dunia branding dapat disebut juga sebagai brand platform.

\section{b. Personal Branding Positioning}

Pada proses ini yang menjadi poin utama adalah hubungan (relationship) dengan komunikasi dua arah antara persona dengan sasaran. Bagi Michael Aldi, komunikasi yang dimaksud adalah dengan pendengar terutama fans setia Michael Aldi. Dengan begitu positioning akan dapat mudah memasuki dan mempengaruhi persepi sasaran (Haroen, 2014). Hal ini dapat dilakukan dengan citra diri, non - verbal (tingkah laku), verbal (informasi individu), dan aksi (performa). Pada Personal branding positioning terdapat empat faktor yaitu:

1. Script merupakan sebuah standar yang menjadi batasan dalam media informasi yang dibagikan seputar dengan informasi individu persona. Hal ini dapat digunakan dalam media seperti pers, berita online, blog, hingga sosial media.
2. Appearance adalah penampilan visual secarafisik. Penampilan tentu harus dijaga sesuai dengan personal branding identity yang telah dibentuk.

3. Manner adalah aspek dari sikap penyampaian atau cara komunikasi individu dengan sasarannya.

4. Verbal juga merupakan bagian dari interaksi penggemar atau sasaran dengan Michael Aldi. Komunikasi secara langsung dengan ide strategi untuk meningkatkan impression dan engagement pada Michael Aldi. Hal ini termasuk juga dengan brand campaign.

\section{c. Personal Branding Assessment}

Pada proses ini merupakan hasil atau output dari personal brand yang dibangun. Dengan mengumpulkan feedback atau respon serta evaluasi penilaian dari sasaran. Assessment sangat dipengaruhi oleh konsistensi personal branding yang telah dibentuk.

\section{Personal Branding Identity}

\section{Role Standard}

\section{Target Audience}

Berikut ini adalah target audience dari Michael Aldi:

Demographic : Pria dan perempuan berumur 18 s.d. 24 tahun, berprofesi sebagai Mahasiswa.

Geographic : Bertempat tinggal atau menempuh pendidikan di Pulau Jawa dan Bali. Sebagian besar menempuh di universitas negeri.

Technographic: tipe joiners yaitu aktif menggunakan sosial media dan mengatur profile sebagai tanda citra dirinya. Collectors yaitu suka mengumpulkan infromasi dan membagikan kepada orang dekat di lingkungannya maupun publik. Spectators merupakan seseorang yang membaca dan mencari referensi serta ilmu dari media digital. Menggunakan media sosial sebagai hiburan saat waktu luang, tidak dapat dilepaskan dari gadget mereka. Menurut mereka, selain dari rekomendasi teman, mereka menemukan atau mengenal penyanyi baru berasal dari banyak platform seperti Youtube, radio, Instagram, dan lainnya. Hal ini juga dikarenakan mereka dekat dengan sosial media, sehingga sangat penting untuk memanfaatkan sosial media yang ada sebagai media strategi.

Psychographic : Mahasiswa gejala atau mengalami college depression. Merupakan seseorang yang mengetahui bahwa dirinyabukan seseorang yang sempurna masih perlu banyak 
belajar sehingga menjadi orang yang lebih baik di kemudian hari. Mereka sadar akan tanggung jawab yang harus mereka selesaikan baik mengenai perkuliahan atau kehidupan mereka. Mengerti bahwa dirinya memiliki hak untuk beropini dalam publik. Memiliki pertemanan yang luas paling tidakmemiliki kumpulan pertemanan yang sangat dekat.

\section{Behavioral : Menganggap musik sebagai} media yang dekat dengan dirinya atau menyukai musik selain itu juga mau mendengarkan musik Indonesia. Merasa karya bangsa juga dapat berkualitas, ingin berbagi hal baik atau bagus secara publik sebagai salah satu aksi daripeduli terhadap sesama, merasa open minded tentang membagikan hal pribadi seperti terbuka saat menceritakan pengalaman. Sangat suka jika dibantu dan merasa perlu bantuan, memerlukan sesuatu atau sosok yang dapat menghibur atau mengisi kekosongan merekadisaat mereka mengalami kepenatan dalam menyelesaikan tanggung jawab mereka. Tidak mau ketinggalan trend dan mereka menyukai hal asli, terbuka tidak dibuat buat, sederhana namun tetap menarik. Mengikuti hal yang menurut mereka relateable dan familiar dengan pengalaman yang mereka alami.

\section{Consumer Insights}

Menurut hasil riset mahasiswa yang pernah mengalami depresi, disaat mereka mengalami tekanan, mereka memilih cara kegiatan yang dapatmelepaskan kepenatan dan mengisi kekosongan dalam diri mereka. Kekosongan tersebut adalah perasaan sendiri. Kesepian atau merasa sendiri berhubungan erat dengan depresi. Dalam penelitianLaasgard, Goossens dan Elklit (2010) menjelaskan bahwa depresi dapat dikaitkan dengan kesepian dari dalam diri seseorang (intrapersonal). Kesepian dan depresi pada mahasiswa memiliki hubungan yang saling mempengaruhi dan dapat berdampak negatifhingga bunuh diri. Selain itu ciri khas tipe kepribadian introvert dan ekstrovert tidak mempengaruhi timbulnya kesepian pada diri seseorang. Dijelaskanpada Brian Little seorang professor dan juga psikolog pada TED Talks-nya bahwa memang betul seorang ekstrovert lebih membutuhkan stimulan untuk membuat dirinya nyaman, dengan berkumpul dengan banyak orang. Sedangkan pada introvert lebih nyaman dengan dirinya bila mengurangi stimulan seperti di tempat tenang sendiri namun bukan berarti merekabiasa saja bila mengalami kesepian. Menurutinterview yang perancang lakukan kepada beberapa orang introvert yang pernah mengalami kesepian, mereka merasa bahwa dirinya tertekan karena kesedihan yang mereka rasa serta selalu mempertanyakan apakah semua ini salah mereka dan apakah diri mereka tidak berharga sehingga mereka merasa kesepian. Dengan kesimpulan bahwa tidak tergantung pada tipe kepribadian orang, setiap seseorang yang mengalami keadaan dan situasi yang menekan mereka dan telah mencapai puncak dari emosional, akan berdampak seperti kesepian dan depresi. Menurut Olivia Remes pada TEDtalknya yang membahas tentang loneliness, bahwa 'small resolve big impact' lewat kutipan ini yang dimaksud adalah perubahan kecil lewat hal sederhana dapat memberikan dampak besar pada seseorang yang mengalami kesepian. Dalam hal ini sosok teman memiliki peran besar dalam kehidupan mahasiswa. Karena dengan perasaan tidak sendiri atau dirinya merasa ada seseorang yang memahami apa yang mereka rasakan, mereka mendapatkan sebuah dukungan serta pengharapan bahwa mereka bukan satu satunya yang mengalami masalah. Maka consumer insight dari perancangan ini adalah setiap mahasiswa membutuhkan 'sosok teman' yang membuat diri mereka tidak merasa sendiri.

\section{Brand Essence}

Berikut ini adalah penjabaran brand essence dari Michael Aldi, yaitu:

Manfaat : Musik Michael Aldi dapat memberikan semangat dan perasaan tenang.

Makna : Musik Michael Aldi dapat sebagai media komunikasi untuk menyampaikan apayang sulit disampaikan.

Differentiator : Michael Aldi memiliki fokus khusus dalam membantu mahasiswa menghadapi college depression. Michael Aldi menerapkan filosofi langit dalam dirinya.

Source of Authorities : Michael Aldi merupakan seseorang yang pernah mengalami college depression. Aldi telah aktif merilis karyanya di platform resmi secara profesional seperti Youtube, Instagram, Apple Music, Joox dan Spotify, dengan jumlah pendengar Spotify sebanyak 72.700 orang.

Personalities : melankolis namun dekat dan akrab dengan teman-temannya, sukamelakukan hal asik bersama temannya, merupakan teman yang setia, perhatian pengerti, terbuka, dan mau membantu mendengar 'curhatan' teman-temannya. Pemikir, tidak menyukai hal terburu buru, tenang, sederhana, dan kalem. 
Brand Archetype : Michael Aldi adalah "The Caregiver" karena sesuai dengan tujuan serta karakteristik Michael Aldi, yaitu memiliki tujuan utama sebagai sebuah brand untuk membantu, memberikan perasaan aman, serta berfokus pada kemurahan hati (generosity) dan kasih sayang (compassion). Sesuai dengan tujuan Michael Aldi untuk membantu mahasiswa menghadapi college depression lewat karyanya. Caregiver brand akan selalu memberikan perhatian serta menjaga kesejahteraan targetnya serta memiliki strategi untuk selalu membuka tangan siap menolong bagi yang membutuhkan. Motto caregiver adalah dengan konsep 'lakukanlah orang lain seperti diri mereka sendiri. Salah satu kelemahan caregiver brand adalah ketidakstabilan. Brand experience dari caregiver adalah membuat orang lain merasa nyaman dan merasa diperhatikan (Connor, 2019).

Maka brand essence dari Michael Aldi adalah Aldi merupakan teman yang selalu ada untuk targetnya.

\section{Filosofi Langit}

Aldi sangat tertarik dan menyukai langit sehingga ia menerapkan filosofi langit pada dirinya. Langit merupakan hal indah yang bersifat universal karena selalu ada dan semua orang dapat lihat. Maka dari itu secara tidak langsung langit menjadi hal perantara atau mutual friend bagi setiap orang. Selain itu langit memiliki banyak warna yang dipengaruhi oleh cuaca sehingga jika di personifikasikan, dapat menjadi sebuah simbolik dari perasaan seseorang. Banyak interpretasi langit bagi setiap orang karena letaknya berada diatas maka sering kali menjadi simbolik surga yang membawa pengharapan dan hal ini didasari oleh psikologi manusia terhadap gerakan alam khususnya awan (Kellert, Heerwagen, \& Mador, 2008). Pergerakan alam memberikan perasaan refresh, sesuatu yang spesial, dan energizing. Sehingga dari segi visual, langit sangat memberikan perasaan positif dari keindahan dan dapat memberikan perasaan tenang secara langsung dan dapat dihubungkan dengan college depression.

\section{Positioning}

Positioning dari Michael Aldi sebagai musisi adalah Aldi sebagai seorang teman bagaikan langit yang selalu ada.

\section{Brand Naming}

Sebelumnya Michael Aldi menggunakan nama panggung Michael Aldi, namun sesuai dengan positioning, menurut riset teman-teman Michael Aldi akrab memanggil dirinya dengan sebutan 'Aldi', Sehingga agar terkesan lebih akrab sebagai teman, nama panggung Michael Aldi menjadi 'Aldi'.

\section{Role Style}

\section{Brand Style}

Positioning dari Personal brand Aldi adalah Aldi adalah sebagai seorang teman bagaikan langit yang selalu ada. Maka dari itu kata kunci yang diambillewat dari riset menurut target makna dari teman selalu ada dan dari filosofi ciri ciri langit, persona yang dibuat memiliki kata kunci utama:

1. Friendship

2. Caring

3. Calming

4. Reliable

5. Approachable

6. Real

7. Personal

8. Langit

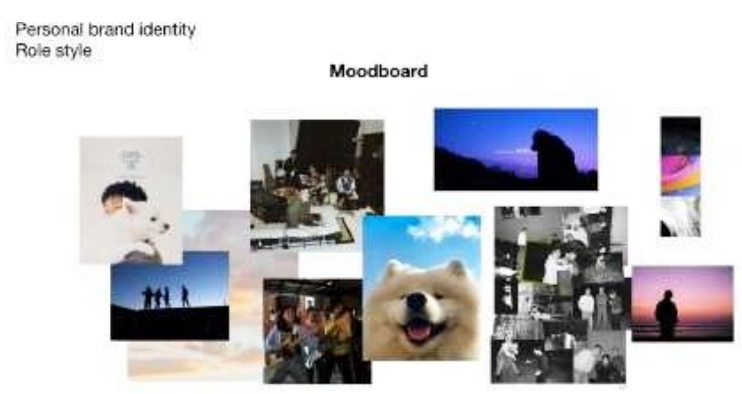

Gambar 1. Moodboard Michael Aldi

\section{Personal Branding Positioning}

\section{Script Brand Narrative}

Michael Aldi merupakan mahasiswa biasa, namun sangat mencintai musik. Tidak selancar cintanya pada musik, Aldi memiliki banyak lika liku dalam masalah percintaan. Cinta bukan hanya hubungan pasangan, tetapi lingkungan sekitar hingga dirinya sendiri. Banyak pertanyaan Aldi yang tak terjawab. Jatuh sering Aldi rasakan, namun setiap kali Aldi memandang langit, Aldi teringat bahwa dirinya tidak pernah sendiri, sama seperti langit yang selalu ada, teman dan keluarga juga selalu bersama Aldi dan tentunya musik. 
Selain sebagai teman, bagi Aldi musik juga bagaikan indera yang mampu berkomunikasi mengutarakan yang Aldi sulit katakan. Musik selalu ada di sekitar Aldi dan menjadi bagian dari Aldi. Sekarang Aldi membuat musiknya sendiri dan mempunyai mimpi musik nya juga dapat membantu banyak orang.

\section{Appearance}

Pertama adalah cara berpakaian Aldi (wardrobe essentials) dengan kata kunci friendly dan mature membutuhkan pakaian yang rapi sehingga memberikan kesan yang reliable serta approachable. Yaitu menggunakan luaran (outer) yang dapat berupa jaket atau kemeja serta menggunakan jaket bertopi (hoodie). Namun tidak meninggalkan kata kunci comfortable, Aldi menggunakan pakaian yang sesuai dengan perannya seorang mahasiswa sertamenggunakan tangan panjang karena Aldi lebih nyaman dengan lengan panjang. Menggunakan asesoris tambahan seperti kacamata, sepatu, dan topi. Walaupun dengan style yang tidak mencolok, dari warna dapat dipadukan dengan satu tone dan konsep dari warna menggunakan filosofi langit seperti pakaian mencerminkan biru langit dengan memakai warna biru dipadukan dengan denim.

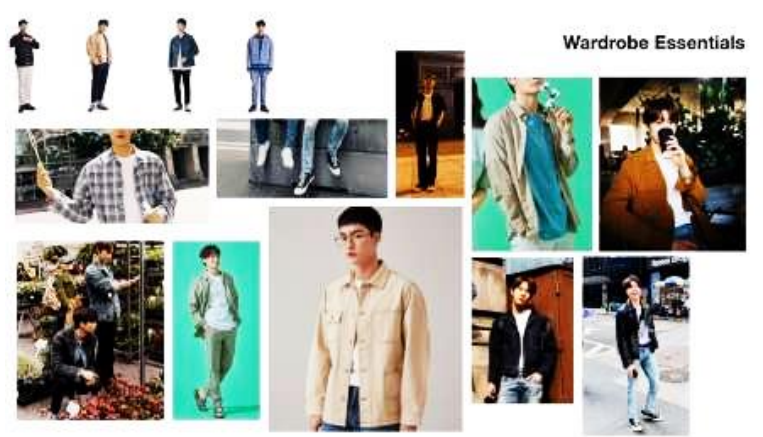

Gambar 2. Referensi Wardrobe Essentials Aldi

Warna atau suatu objek yang mengingatkan pendengar terhadap Aldi (personal colors) adalah warna dan visualisasi dari langit. Dengan kata kunci pada personal brand Aldi menggunakan calming dan colorfull dari filosofi langit sehingga menerapkan warna dari langit seperti biru pagi dan siang hari, warna matahari terbenam dan terbit, dan juga warna di saat malam hari.

Warna pada Gambar 3 juga diterapkan pada tone foto yang digunakan dalam desain grafis dari karya Aldi. Karena Aldi memiliki hobi fotografi, maka arahan untuk desain Aldi banyak meng-gunakan latar foto daripada latar dengan blok warna.

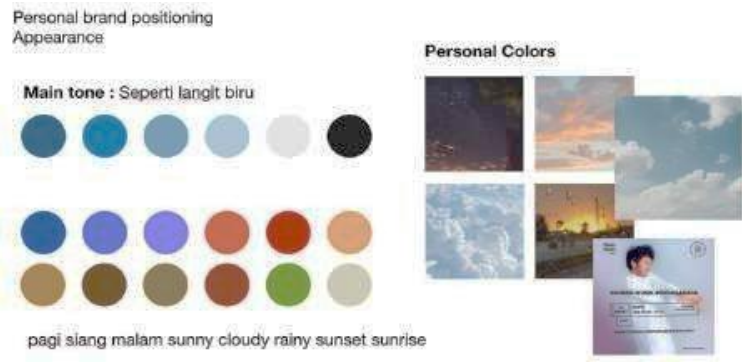

Gambar 3. Personal Colors Aldi

\section{Manner dan Verbal}

Arahan kepribadian dalam personal branding Aldi adalah sosok teman yang selalu ada menemani dan nyaman menjadi teman bercerita bagi pendengar karena Aldi merupakan seseorang pendengar yang baik, memiliki karakternya yang netral, tidak judgemental, mature, reliable, dan dapat menenangkan (calming). Namun merupakan seorang yang terbuka humoris dan asik sehingga membuat dirinya seseorang yang approachable. Sikap Aldi menunjukan bahwa dirinya memiliki banyak pengalaman dalam beberapa masalah dan yang ditunjukan Aldi sosok yang tegar dan tidak mudah menyerah (supportive) dan selalu perhatian memberikan solusi terbaik. Saat Aldi membantu temannya, Ia memiliki cara selalu berdiskusi (melibatkan pendengar). Maka dari itu arahan untuk manner dan verbal Aldi adalah:

a. Tone suara Aldi saat berbicara adalah tipe suara deep, tenang namun tidak ragu memberikan kesan mature dan reliable sehingga menimbulkan kepercayaan. Jika diberi pertanyaan secara langsung Aldi akan mengambil paling tidak 5 detik untuk berpikir sebelum menjawab. Body Languange saat Aldi mendengarkan seseorang bercerita yaitu sering mengaggukkan kepala tanda meresapi cerita yang didengar dan memberikan respon dengan mengatakan "ya" dengan pelan tanda mengerti apa yang dibicarakan. Kecepatan saat berbicara juga tidak terlalu lambat saat tidak terlalu cepat disesuaikan dengan kondisi situasi topik yang dibicarakan.

b. Verbal/Power words Aldi adalah menggunakan kalimat santai pemilihan kata yang tidak selalu puitis namun mengandung makna dan berbahasa Indonesia. Power words Aldi adalah "dijalani" dan "bersama sama" karena cara Aldi saat memberikan jawaban dengan cara melibatkan pendengar. Aura yang dibawa Aldi positif dan suportif. 


\section{Strategi Komunikasi}

Strategi komunikasi Aldi adalah berfokus pada fans, pendengar, pengikut Aldi adalah teman dekat Aldi. Aldi memberikan perhatian layaknya seorang teman dekat yang selalu mengingatkan hal hal baik untuk target yaitu yang juga merupakan mahasiswa, seperti mengingatkan untuk tidur cukup, menyemangati saat kerja tugas, mengajak mencoba kegiatan baru, dan lainnya. Maka dari itu dari perancangan ini memanfaatkan fitur Live Instagram dengan yang dapat merupakan bagian brand campaign dan promosi musik baru. Banyak melakukan komunikasi secara langsung (Live) dan tidak langsung dengan konten terjadwal. Tidak ada sebutan khusus untuk Aldi memanggil pendengarnya.

Konten Aldi akan diunggah pada jam mahasiswa mengerjakan tugas atau disaat mereka waktu luang yaitu pukul 18.00 dan 22.00 WIB.

\section{Strategi Konten}

Dalam stategi konten Aldi memiliki tahapan tujuan, yang pertama yaitu untuk memperkenalkan (introduce) brand dan image Aldi setelah memiliki personal brand. Lewat perkenalan ini target akan lebih memahami sosok Aldi sebagai musisi dan juga sebagai arahannya yaitu teman yang selalu ada. Pada tahap ini juga dapat membentuk komunitas atau Aldi yang menyesuaikan dengan karakteristik komunitas target, sehingga menimbulkan perasaan relateable dan familiarity. Yang kedua adalah membiasakan target dalam kesehariannya ditemani oleh Aldi, dengan strategi konten yang juga disesuaikan dengan aktivitas dan kebutuhan target yaitu yang membutuhkan teman dan sosok yang dapat menurunkan tekanan college depression mereka. Kedua tahap ini memiliki content pillar utama yaitu Identity sebagai konten tahap perkenalan (awareness), lalu Engagement sebagai konten tahap kedua (membiasakan target ditemani oleh Aldi) dan yangterakhir dapat disisipkan konten Promotions.

\section{Identity}

Pada bagian identity terfokus pada penjelasan positioning dan brand story Aldi yaitu sebagai seorang teman. Sehingga konten strategi yang dibuat menggunakan konsep dokumenter kreatif dari point of view Aldi sebagai teman dan musisi. Pada bagian ini terdapat konten dengan media sosial Instagram yang memperlihatkan aktivitas Aldi dengan teman dan tim musiknya, hobi dan kesenangan Aldi tentang filosofi langit.

\section{DOCUMENALDI - Mini Documentary}

Documenaldi berasal dari kata documentary dan Aldi,namun juga dapat di artikan sebagai dokumen milik Aldi. Documenaldi adalah sebuah video perkenalan dari seorang Aldi yang dibagi menjadi dua bagian. Part satu dengan judul 'DOCUMENALDI: Open Archive', memiliki jalan cerita membuka kenangandan cerita lama asal mula Aldi masuk ke dunia musik.

Bagian kedua 'DOCUMENALDI: Friends in Me' yaitu menceritakan bahwa peran musik sebagai teman Aldi dan juga teman teman Aldi yang selalu ada di setiap perjalanan karir musiknya sehingga Aldi mampu melanjutkan dan berani untuk berkarya.

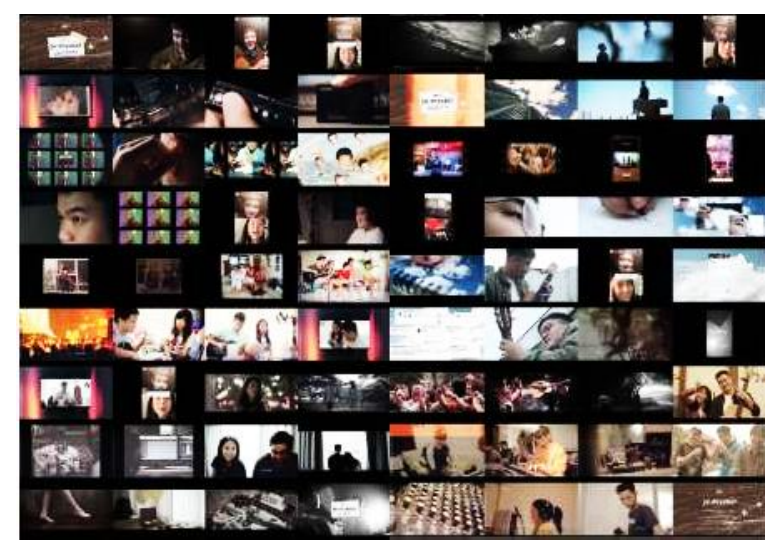

Gambar 4. DOCUMENALDI - Open Archive

Sumber: https://youtu.be/h2sNEQyDi9I , https://youtu.be/dxGSFStMaT8

\section{Engagement}

Konten engagement memilik fokus pada membangun interaksi atau membiasakan target ditemani oleh Aldi dan merupakan bagian dari college depression campaign Aldi. Media yang digunakan adalah Instagram Live dan juga mengandung konten promosi (pre release) yang menjadi sebuah konten ekslusif.

Instagram Live Aldi memiliki jadwal setiap hari Jumat sebagai hari membuka akhir pekan dan Senin sebagai hari memulai awal minggu. Judul untuk hari Jumat adalah "Apa Kabar Akhir Pekan" sebagai bentuk sapaan dan judul hari Senin adalah "Ask All di Live", menggunakan permainan kata 'All' dan 'di'menjadi 'Aldi' dan mengandung makna dapat bertanya maupun request Aldi apapun di Live.

Pemilihan design poster disesuaikan dengan media yang dekat dan se-real mungkin, seperti 
menggunakan fitur kamera, messanger, dan media sosial. Karena lewat media yang dekat target akandapat merasakan relate dan terasa bagaimana Aldi sangat real tanpa adanya editan design yang berlebihan.
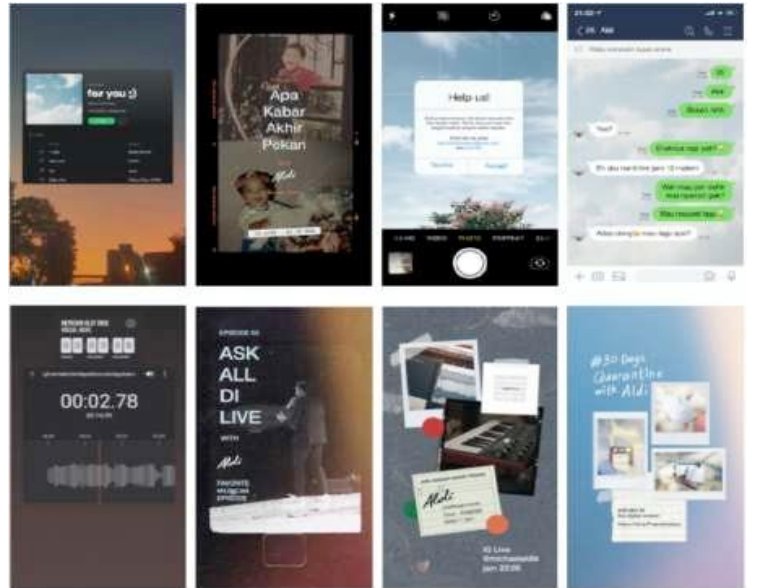

Gambar 5. Poster Live Aldi

\section{Promotion}

Promotion merupakan bagian konten yang fokus pada promosi karya Aldi. Pada bagian ini terdiri dari ide kreatif untuk pendukung karya Aldi yang akan dirilis. Untuk meningkatkan hype menciptakan suasana yang dinanti nantikan bagi penggemar Aldi. Selain itu konten promosi juga bertujuan untuk menyebar luaskan karya Aldi sehingga banyak target baru yang menjadi pedengar Aldi. Namun karena fokus dari perancangan ini pada awareness Aldi, strategi promosi akan di selipkan dalam konten Identity dan Engagement

\section{Aplikasi Media}

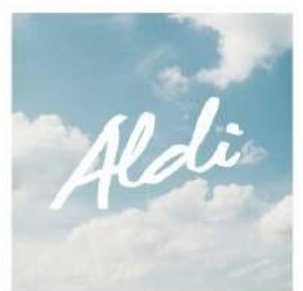

Gambar 6. Logo Aldi

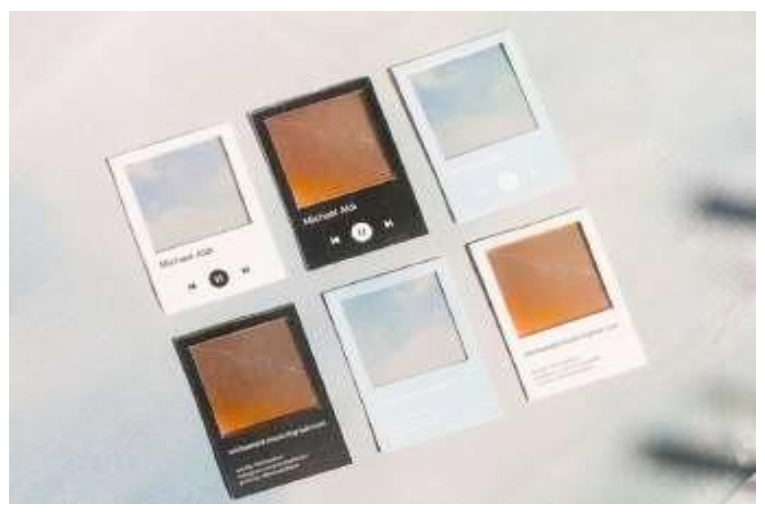

Gambar 7. Name Card Aldi
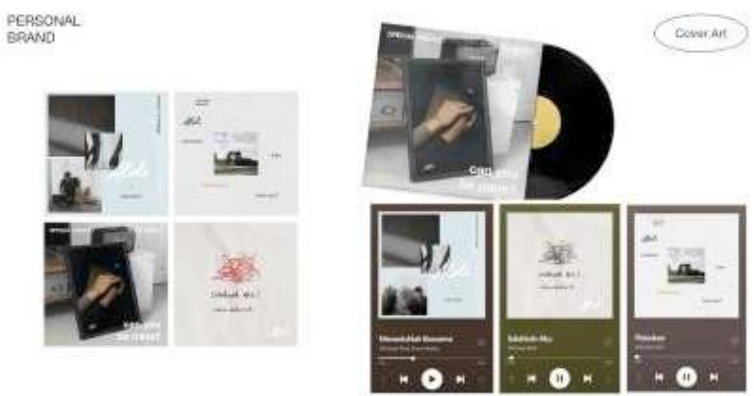

Gambar 8. Cover Art Album Aldi Tampilan Media Sosial
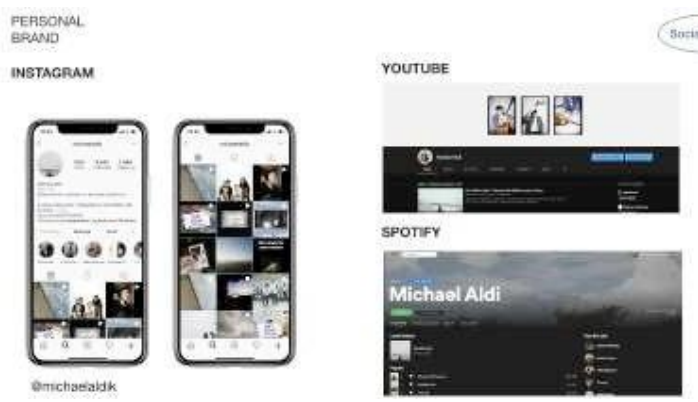

Gambar 9. Tampilan Media Sosial Aldi

\section{Merchandise}

Sebenarnya Aldi belum pada tahap brand yang siap menjual sebuah merchandise, sebagai gantinya strategi yang dibuat dengan mengambil nilai dari sebuah barang yang biasa target terima atau berikan kepada teman baik mereka. Salah satunya surat atau pesan semangat lewat memo. Dengan situasi yang dialami tahun ini yaitu karatina pandemi Covid - 19, mengharuskan banyak orang yang harus tetap dirumah. Hal ini menyebabkan target menjadi lebih penat hingga mengalami depresi. Sesuai denganarahan Aldi yang dapat menjadi teman agar mengurangi tekanan depresi mereka, ide merchandise yang dibuat adalah '\#30DaysQuaratineWithAldi'. Selain dapat selalu 'keeping up' dengan konten aldi setiap hari, strategi ini memiliki tujuan sebagai sosok yang selalu diingat setiap hari selama masa karantina ini, target dapat melakukan sebuah hal sederhana namun bersifat positif dan membawa kebaikan baik diri sendiri maupun org lain lewat Aldi. Merchandise ini juga dapat bersifat sebagai turunan dari sebuah college depression campaign Aldi. Sifatnya online (campaign) dan offline (merchandise).

Pada online (campaign), \#30DaysQuaratineWithAldi memiliki konsep yang sederhana menggunakan sebuah Post-it (memo) di bagikan via Instagram Story. Pemilihan konsep aktivitas terfokus pada menemani dan memberikan kegiatan positif sesuai dengan teori bagaimana mengurangi tekanan menghadapi college depression. Selain lewat Story, terdapat juga 
virtual Friendship box dapat diakses via Google Drive. Di dalamnya terdapat memo yang sama, sticker dalam file PNG, dan terdapat juga template yang dapat digunakan untuk daily journaling dan target dapat menulis cerita tanpa harus menulis nama. Untuk cerita yang menarik akan Aldi share di media sosialnya. Selain itu Aldi juga dapat menjadikan cerita tersebut menjadi inspirasi untuk lagu barunya.

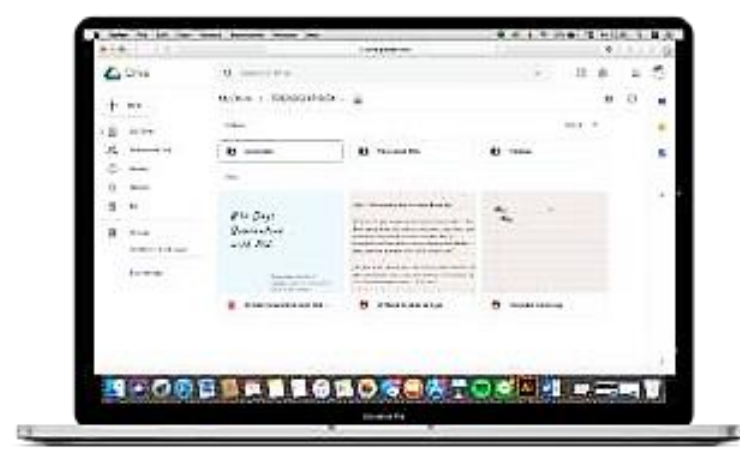

Gambar 10. Tampilan Virtual Friendship Box

Offline (merchandise), \#30DaysQuaratineWithAldi memiliki sifat lebih formal atau official. Sehingga pada output eksekusi tetap menggunakan design yang personal namun dengan teknik printing yang rapi. Dikemas dalam bentuk sebuah box dari kaleng sebagai symbol 'time capsule' identik sebagai sebuah wadah yang dapat menyimpan memori dengan teman atau sahabat. Post- it juga memiliki beda versi dengan online yaitu dapat digunakan sebagai memo asli, namun tidak meninggalkan value dan tujuan dari merchandise ini yaitu menjadi teman dan penyemangat dalam masa karantina. Selain berisi memo, juga berisi alat tulis, sticker pack, essential oil dan kartu nama promosi Aldi.

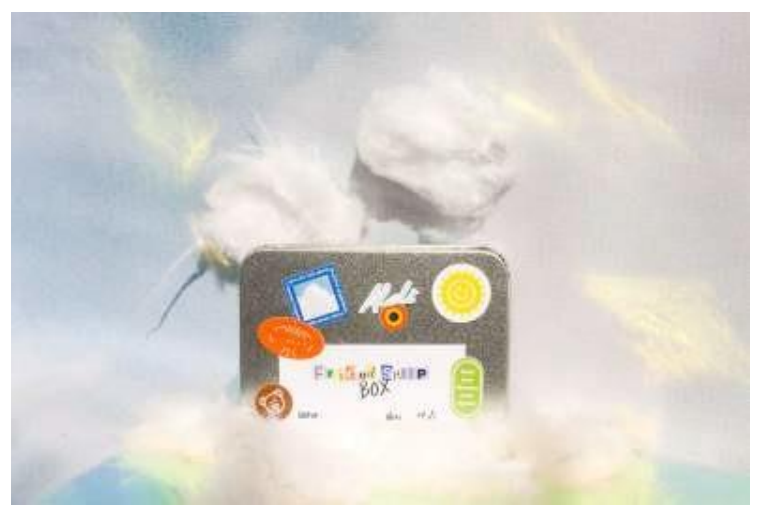

Gambar 11. Detail isi Friendship Box Aldi

\section{Personal Branding Assesment}

Berikut adalah hasil evaluasi dari Interview beberapa penonton dan fans Aldi. Interview dengan pertanyaan apakah mereka merasakan perbedaan dengan Aldi akhir akhir ini. Hasil interview menyimpulkan bahwa mereka merasa Aldi semakin sering muncul dalammedia sosial khususnya Instagram, mereka merasa Aldi semakin banyak interaksi dengan pengikutnya, mereka juga merasa Aldi lebih menunjukkan sosok perhatian, karena sering melakukan Live, menurut mereka public speaking Aldi semakin lancar. Sebagian dari mereka menonton Live Aldi disaat mereka mengerjakan tugas, beristirahat, dan disaat mereka bosan di malam hari. Alasan paling banyak untuk mereka yang menonton Live dari awal hingga akhir karena mereka menyukai suara Aldi, menurut hasil dari review Live, penonton paling banyak disaat Aldi live dengan konten request musik. Alasannya karena mereka suka dengan suara Aldi dan ingin mendengar lagu favorit mereka versi Aldi.

Interview dilanjutkan dengan feedback, kritik dan saran dari video DOCUMENALDI. Hasil kesimpulan dari jawaban mereka adalah, mereka merasa semakin mengenal Aldi, mereka juga menyebutkan bahwa mereka jadi memahami proses dari seorang musisidan jadi lebih menghargai musik dan sebagian besar dari mereka terharu disaat bagian beratnya perjalanan Aldi (DOCUMENALDI PART 2). Ada yang berkomentar setelah menonton DOCUMENALDI, ia semakin ingin dukung dan menjadi teman Aldi. Dari beberapa teman Aldi juga tanpa menyadari merasa semakin mengenal Aldi dan merasa diapresiasi karena ternyata dukungan yang diberikan mampu membawa Aldi hingga sekarang.

Setelah itu interview dilakukan pada pendukung setia Aldi, mereka mengatakan saat interaksi live sangatmerasa dekat dengan Aldi seperti teman dekat sendiri, salah satu dari mereka menyebutkan terkadang Aldi juga dapat menjadi seperti saudara yang lebih tua, mereka menjelaskan disaat waktu kosong mereka konten aldi menemani dan menghibur mereka, mereka juga menyebutkan bahwa mereka sangat menyukai suara aldi yang menenangkan dan lembut, Live Aldi juga menemani mereka disaat mereka beraktivitas.

Hasil kesimpulan dari evaluasi, konten yang dibuat sudah menyebarkan musik Aldi lebih luas lagi, dapat dilihat dari banyak profile visit media sosial Aldi.

Selain itu lewat tanggapan target lewat konten Aldi mereka semakin mengenal sosok Aldi yang sebenarnya bahkan seperti mereka sen- 
diri, Aldi juga sering berinteraksi ditambah juga terdapat konten kolaboratif dengan pengikut Aldi dan responnya sangat positif. Yaitu konten mengirimkan foto langit mereka ke Aldi via email atau DM, hal ini meningkatkan engagement dan impression pada Aldi, walaupun dengan posting konten setiap hari sebelumnya angka engagement, impressions, danjumlah followers sangat mudah naik dan turun drastis.

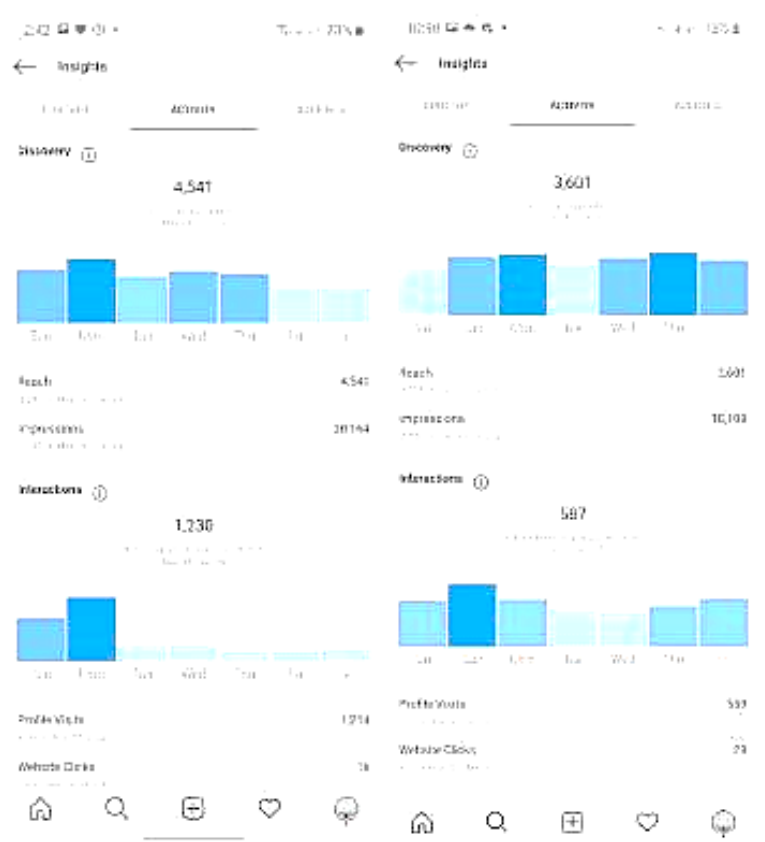

Gambar 12. Insights Instagram Aldi

\section{Kesimpulan dan Saran}

Memang betul bahwa college depression merupakan depresi yang lazim ditemui, terutama di Indonesia dengan era sekarang dimana persaingan serta teknologi semakin maju dan pesat. Peran sosial sangat berperan besar dimulai dengan komunikasi, interaksi, hingga koneksi. Sangat pentingnya dukungan dan semangat terutama secara emosional bagi mahasiswa zaman sekarang. Namun terkadang disaat situasi tidak mendukung dan mahasiswa membutuhkan dukungan itu, mereka memerlukan sosok yang dapat mengisi kekosongan mereka. Salah satu media yang paling dekat dengan musik. Michael Aldi sebelumnya belum memiliki brand identity yang jelas serta konten yang konsisten menyebabkan musiknya tidak sampai kepada target dengan tepat. Lewat perancangan personal brand ini menjawab dari tujuan perancangan yaitu Michael Aldi dapat berkontribusi mem-bantu pendengarnya untuk merasa tidak sendiri dengan menemani lewat musiknya, sehingga banyak dari mereka dapat me-ngurangi tekanan yang mereka alami. Selain itu Aldi mengalami perkembangan baik dari segi semakin banyak orang mengenal Aldi dan bagi pengikut Aldi menjadi semakin dekat dengan Aldi sebagai sosok 'teman' mereka. Aldi dapat menemani mereka, berbagi pemikiran, tidak hanya itu juga menghibur mereka pada saat mereka membutuhkan. Hal ini menyebabkan semakin melekatnya pengikut dengan Aldi. Baik dari pengikut maupun dari Aldi sendiri merasakan 'healing' atas kesepiannya dari perancangan ini.

Untuk perancang selanjutnya yang ingin merancang dan mengembangkan dengan topik serupa, ada beberapa saran untuk diperhatikan. Diharapkan untuk memaksimalkan konten secara offline misalnya dengan Live performance, mini concert, serta untuk konten online lebih bervariasi lagi.

Untuk rencana selanjutnya mencoba untuk membuat original content untuk konsistensi konten, serta berkolaborasi dengan musisi lain dalam kegiatan sederhana pun dapat meningkatkan dan menyebarkan musik Aldi. Selain itu menurut evaluasi sangat penting media pers, seperti press release, press conference, live performance dengan mengundang media secara resmi untuk meningkatkan kredibilitas dan penyebaran lewat media resmi. Namun dengan keadaan tidak mendukung (pandemi Covid-19) diharapkan dikemudian hari dapat direalisasikan. Walaupun dengan era online, Live performance secaraoffline masih menjadi jalan utama untuk dapat meningkatkan promosi dan penyebaran lebih luas karena bertemu target baru. Yang terakhir adalah sebenarnya sangat penting untuk memperkuat target terdekat sebelum memperluas target yang lebih jauh lagi. Hal ini juga dapat dilakukan bersamaan, memperkuat dan memperluas dengan konten. Tentu objektif dari strategi konten harus berubah dan berkembang menjadi lebih kuat lagi bagi brand Aldi.

\section{Daftar Pustaka}

Ahsan, I. A., \& Khalika, N. N. (2019, January 7). Depresi Karena Skripsi, Kampus \& Dosen Wajib Menolong Mahasiswa. Retrieved from https://tirto.id/depresi-karena-skripsikampus-dosen-wajib-menolong-mahasiswa Danhauer, K. J. (2005). Music as Therapy. Southern Medical Journal.

DeAnnah R. Byrd MS \& Kristen J. McKinney $\mathrm{PhD}$. (2012). Individual, Interpersonal, and Institutional Level Factors Associated with 
the Mental Health of College Students, Journal of American College Health, 60:3, 185-193, 10.1080/07448481.2011.584334

Haroen, D. (2014). Personal Branding. Jakarta: PT Gramedia Pustaka Utama.

Kedher, M. (2013). Power Branding: Towards Conceptualization. International Conference of Business, Economics, Marketing, \& Management, $2,7-12$.

Kellert, S. R., Heerwagen, J., \& Mador, M. (2008). Biophilic Design: The Theory, Science and Practice of Bringing Buildings to Life.

Laasgard, M., Goossens, L., \& Elklit, A. (2010). Loneliness, Depressive Symptomatology, and Suicide Ideation in Adolescence: Cross-
Sectional and Longitudinal Analyses.

"Music Therapy for Depression: An Efficient, Cost-Effective Way to Treat Children and Teens". (2014, October 22). Retrieved February 5, 2020, from www.medicaldaily.com: https://www.medicaldaily.com/musictherapy-depression-efficient-cost-effectiveway-treat-children- and-teens-307725

Rampersad, H. K. (2008). Authentic Personal Branding: A New Blueprint for Building and Aligning A Powerful Leadership Brand. North Carolina: Age Publishing Inc.

Wiryawan, M. B. (2008). Kamus Brand A-Z. (V. Wardana, \& D. K. Homan, Eds.) Jakarta, Indonesia: Red \& White Publishing. 